\title{
Influence of concomitant heparin administration on pregnancy-associated plasma protein-A levels in acute coronary syndrome with ST segment elevation
}

\author{
Petr Hájek리 Milan Macek Sr. ${ }^{2}$, Andrej Lashkevich², Hana Klučková², Marie Hladíková2, \\ Eva Hansvenclová1, Martin Malý1, Josef Veselka', Alice Krebsováa
}

1Cardiovascular Center, Department of Cardiology, Charles University and University
Hospital Motol, Prague, Czech Republic
2Department of Biology and Medical Genetics, Charles University and University
Hospital Motol, Prague, Czech Republic
3Department of Internal Medicine/Cardiology, Virchow Klinikum, Humboldt University,
Berlin, Germany

Submitted: 14 September 2010

Accepted: 30 November 2010

Arch Med Sci 2011; 7, 6: 977-983

DOI: 10.5114/AOMS.2011.26609

Copyright (C) 2011 Termedia \& Banach

\section{Abstract}

Introduction: The time course of pregnancy-associated plasma protein-A (PAPP-A) levels was studied at admission, immediately after percutaneous coronary intervention ( $\mathrm{PCl}$ ) and 1, 2, 4, 6, 12, 24 and $48 \mathrm{~h}$ after $\mathrm{PCl}$ in acute coronary syndrome with ST segment elevation (ACS-STE) to determine the impact of $\mathrm{PCl}$, concomitant clinical complications and heparin administration.

Material and methods: Pregnancy-associated plasma protein-A serum levels, examined by the Kryptor ${ }^{\mathrm{TM}}$ system, were studied in 30 heparinized PCI ACS-STE patients, in 10 elective PCls and 12 coronary angiographies with heparin, and in 5 patients with normal coronary angiogram without heparin.

Results: Heparin caused a high PAPP-A increase in ACS-STE patients, in all patients with heparin without ACS and angiographic signs of significant atherosclerosis. This increase was directly associated with heparin dosage and activated clotting time (ACT) $(r=0.71, p=0.0001)$ and inversely with the interval between heparin applications and time of serum sampling. It was followed by a rapid decrease within 1 to $2 \mathrm{~h}$ and return to normal levels in 10 to $12 \mathrm{~h}$. In ACS-STE patients the decrease was significantly slower than in heparinized elective $\mathrm{PCl}$ and angiography patients. The PAPP-A increase was not significantly dependent on the length of $\mathrm{PCl}$. Persistent increase after $24 \mathrm{~h}$ was associated in 4/7 patients with concomitant clinical complications.

Conclusions: The diagnostic validity of PAPP-A can be verified only within the $1^{\text {st }} \mathrm{h}$ after clinical onset of ACS before heparin administration, the prognostic value in heparinized patients not earlier than $12 \mathrm{~h}$ after the last heparin application, if ACT is normal and serious clinical concomitant complications are eliminated.

Key words: pregnancy-associated plasma protein-A, myocardial infarction, heparin, percutaneous coronary intervention.

\section{Introduction}

Examination of increased pregnancy-associated plasma protein- $A$ (PAPP-A) serum levels within the first $12 \mathrm{~h}$ of acute coronary syndrome (ACS) development supports the hypothesis that it might be the earliest marker of different types of ACS [1, 2], because of its presumed role in the

\author{
Corresponding author: \\ Petr Hájek MD \\ Department of Cardiology \\ University Hospital Motol \\ V Uvalu 84, Prague 5 \\ 150 06, Czech Republic \\ Phone: +420603 202796 \\ Fax: +420 224434920 \\ E-mail: petr.hajek@fnmotol.cz
}


development of atherosclerotic lesions [3], atheromatous plaque instability [4] and its contribution to adverse outcomes in ACS [5].

The study of PAPP-A kinetics in ACS patients indicates that its pattern of release is variable. Pregnancy-associated plasma protein-A levels can be influenced by the timing of reperfusion. Its elevation is followed by rapid normalization [6].

Comparison of the effect of primary percutaneous intervention $(\mathrm{PCl})$ and thrombolytic therapy on increased PAPP-A levels revealed that the effect of heparin administration on this increase might not be eliminated [7]. The potential significance of concomitant heparin administration for increased PAPP-A levels in ACS with ST elevation (ACS-STE) was confirmed in animal experiments; heparin administration was associated with a rapid and significant increase in PAPP-A levels, presumably due to the detachment of PAPP-A from vessel walls [8]. This hypothesis was confirmed by a rapid increase of PAPP-A after intravenous application of low molecular weight heparin (LMWH) and unfractionated heparin (UFH) in haemodialysis and angiography patients. Repeated heparin boluses induced additional PAPP-A release [9].

The aim of our work was to study the time course of PAPP-A levels during the early phase of ACS-STE after hospital admission to determine the impact of other associated clinical factors, $\mathrm{PCl}$, and UFH/LMWH administration, including clinical complications.

\section{Material and methods}

\section{Patient population and study design}

The Internal Ethics Review Board of University Hospital Motol approved this prospective study. All study subjects signed informed consent prior to coronary angiography. Clinical data were obtained from 30 randomly sampled ACS-STE patients referred to our department (Table I) between January 18 and August 9, 2007 for primary PCl.

Acute coronary syndrome with ST elevation was characterized by prolonged chest pain with ST elevation (> $1 \mathrm{~mm}$ in leads I, II, III, aVL and aVF or $>2 \mathrm{~mm}$ in two or more contiguous V1-6 leads). The median time from the onset of symptoms to the first sampling was $192 \mathrm{~min}$ (range 75-525 min).

Heparin was administered during transport to the hospital in 29/30 patients (96.7\%); 1 patient arrived without heparin. In 22/30 patients additional UFH concomitant with PCI was applied (ACS-STE + aUFH). In 8/30 patients, no additional UFH, either before or during primary $\mathrm{PCl}$, was used, due to satisfactory anticoagulation (ACS-STE + UFH). Efficacy of anticoagulation therapy during $\mathrm{PCl}$ was monitored using activated clotting time (ACT). Low molecular weight heparin was administered after sheath removal in $12 / 30$ patients (40\%).

The study is based on the exact timing of acute chest pain onset, heparin (UFH/LMWH) administration during transport, the first pre-PCI PAPP-A examination, pre-PCI UFH administration, duration of $\mathrm{PCl}$, and consecutive examinations, starting immediately after $\mathrm{PCl}$ and repeated at 1, 2, 4, 6, 12, 24 , and $48 \mathrm{~h}$ after $\mathrm{PCl}$. Pregnancy-associated plasma protein-A was examined from frozen sera $\left(-20^{\circ} \mathrm{C}\right)$, prepared within $1-2 \mathrm{~h}$ after blood sampling, using the Kryptor ${ }^{\mathrm{TM}}$ (Brahms, Germany) system, which measured total PAPP-A, uncomplexed and complexed, along with the proform of eosinophilic major basic protein (proMBP). Intra- and inter-assay variation coefficients were $7.5 \%$.

For exact evaluation of UFH, PCI and angiography influence on PAPP-A levels, three control groups were selected: 1) 10 patients with elective $\mathrm{PCl}$ receiving $\mathrm{UFH}$ (elective $\mathrm{PCI}+\mathrm{UFH}), 2$ ) 12 patients without $\mathrm{PCl}$, but UFH was administered because of the radial approach or intracoronary ultrasonography $(\mathrm{ANG}+\mathrm{UFH})$, 3) 5 patients without $\mathrm{PCl}$, with coronary angiography performed via the femoral approach, without UFH administration and without angiographic signs of atherosclerosis (ANG-UFH) (Table I). Pregnancy-associated plasma protein-A samples were drawn according to the same time schedule as for ACS-STE, but only within $24 \mathrm{~h}$.

Curves for the PAPP-A time course were derived from median levels and intervals between the start of the $\mathrm{PCl}$ and the end of the procedure for all studied patients. For exact determination of normal PAPP-A cut-off levels, PAPP-A levels of ANG-UFH patients were compared with levels of patients without coronary artery disease (CAD) from our previous study [2].

\section{Statistical analysis}

Nonparametric analyses were used due to the non-Gaussian distribution of PAPP-A and other variables. Basic characteristics included median and total range, eventually inter-quartile range. The Mann-Whitney test was used for two group comparisons, the Kruskal-Wallis test for comparisons among 3 or more groups. Post-hoc pair-wise comparisons (Table II) were done using the method of unweighted groups [10]. The $\chi^{2}$ test or Fisher's exact test was used to compare the occurrence of risk factors among the examined cohorts, Spearman's correlation to evaluate the relationship between PAPP-A and ACT. Statistical analysis was carried out using SPSS software (Release 17).

\section{Results}

\section{Patient characteristics}

The clinical characteristics are documented in Table I. Patients treated with primary PCI were suc- 
Table I. Characteristics of studied patients

\begin{tabular}{|c|c|c|c|c|c|c|c|}
\hline & & $\begin{array}{c}\text { ACS-STE + UFH } \\
(N=8)\end{array}$ & $\begin{array}{c}\text { ACS-STE + aUFH } \\
(N=22)\end{array}$ & $\begin{array}{l}\text { Elective } \mathrm{PCl}+\mathrm{UFH} \\
\quad(N=10)\end{array}$ & $\begin{array}{l}\text { ANG + UFH } \\
(N=12)\end{array}$ & $\begin{array}{c}\text { ANG-UFH } \\
(N=5)\end{array}$ & Value of $p$ \\
\hline \multirow[t]{2}{*}{ Age [years] } & Mean \pm SD & $71.5 \pm 11.8$ & $56.3 . \pm 12.3$ & $64.7 \pm 2.4$ & $64.7 \pm 8.3$ & $53.7 \pm 6.2$ & * \\
\hline & Range & $45.6-85.5$ & $34.1-77.6$ & $61.6-69.5$ & $54.9-84.7$ & $42.8-61.0$ & \\
\hline \multirow[t]{2}{*}{ Sex no. (\%) } & Male & $3(37.5)$ & $17(77.3)$ & $7(70)$ & $6(50)$ & $2(40)$ & NS \\
\hline & Female & $5(62.5)$ & $5(22.7)$ & $3(30)$ & $6(50)$ & $3(60)$ & NS \\
\hline \multirow{11}{*}{$\begin{array}{l}\text { Risk factors } \\
\text { no. (\%) }\end{array}$} & Hypertension & $3(37.5)$ & $10(45.5)$ & $10(100)$ & $11(92)$ & $1(20)$ & * \\
\hline & Smoking & $2(25)$ & $16(72.7)$ & $2(20)$ & $1(8)$ & $1(20)$ & * \\
\hline & $\begin{array}{l}\text { Hyperlipo- } \\
\text { proteinaemia }\end{array}$ & $1(12.5)$ & $9(40.9)$ & $8(80)$ & $9(75)$ & $5(100)$ & * \\
\hline & Diabetes mellitu & us 1 (12.5) & $4(18.2)$ & $4(40)$ & $2(17)$ & $1(20)$ & NS \\
\hline & Diet & $1(12.5)$ & $2(9.1)$ & $1(10)$ & $1(8)$ & $1(20)$ & NS \\
\hline & PAD & $0(0)$ & $2(9.1)$ & $2(20)$ & $1(8)$ & $0(0)$ & NS \\
\hline & Insulin & $0(0)$ & $0(0)$ & $1(10)$ & $0(0)$ & $0(0)$ & NS \\
\hline & $\mathrm{BMI}$ mean $\pm \mathrm{SD}$ & $26.9 \pm 2.9$ & $29.8 \pm 4.9$ & $28.3 \pm 3.6$ & $26.5 \pm 3.8$ & $27.0 \pm 3.8$ & NS \\
\hline & History of MI & $0(0)$ & $1(4.5)$ & $1(10)$ & $0(0)$ & $0(0)$ & NS \\
\hline & History of stroke & e $3(37.5)$ & $1(4.5)$ & $0(0)$ & $1(8)$ & $0(0)$ & NS \\
\hline & $\begin{array}{l}\text { History of } \\
\text { revascularization }\end{array}$ & $1(12.5)$ & $1(4.5)$ & $5(50)$ & $5(42)$ & $0(0)$ & * \\
\hline \multirow{7}{*}{$\begin{array}{l}\text { Therapy } \\
\text { no. (\%) }\end{array}$} & Aspirin & $2(25)$ & $2(9.1)$ & $8(80)$ & $5(42)$ & $1(20)$ & * \\
\hline & $\beta$-Blockers & $3(37.5)$ & $2(9.1)$ & $6(60)$ & $7(58)$ & $2(40)$ & * \\
\hline & ACE inhibitors & $1(12.5)$ & $6(27.3)$ & $9(90)$ & $8(67)$ & $0(0)$ & * \\
\hline & Nitrates & $0(0)$ & $0(0)$ & $3(30)$ & $3(25)$ & $1(20)$ & * \\
\hline & Statins & $0(0)$ & $1(4.5)$ & $7(70)$ & $7(58)$ & $3(60)$ & * \\
\hline & $\begin{array}{l}\text { Calcium channel } \\
\text { blockers }\end{array}$ & $0(0)$ & $1(4.5)$ & $1(10)$ & $1(8)$ & $0(0)$ & NS \\
\hline & Clopidogrel & $0(0)$ & $9(40.9)$ & $4(40)$ & $3(25)$ & $0(0)$ & NS \\
\hline \multicolumn{2}{|c|}{ Ejection fraction (\%) } & 43.9 & 48.1 & 50.8 & 55.6 & 66.3 & * \\
\hline \multicolumn{2}{|c|}{$\begin{array}{l}\text { Mean number of vessels } \\
\text { with stenosis }>50 \%\end{array}$} & 1.6 & 1.6 & 1.1 & 0.0 & 0.0 & NS \\
\hline \multirow{3}{*}{$\begin{array}{l}\text { Culprit } \\
\text { vessel }\end{array}$} & RIA (\%) & $5(62.5)$ & $10(45.5)$ & $4(40)$ & 0 & 0 & \\
\hline & RCX (\%) & 0 & $3(13.6)$ & $2(20)$ & 0 & 0 & \\
\hline & $\mathrm{ACD}(\%)$ & $3(27.5)$ & $9(40.9)$ & $4(40)$ & 0 & 0 & \\
\hline \multirow{3}{*}{$\begin{array}{l}\text { PAPP-A } \\
\text { before } \\
\text { PCl/angio } \\
\text { [mlU/l] }\end{array}$} & Mean \pm SD & $65.3 \pm 26.3$ & $30.2 \pm 22.7$ & $7.8 \pm 2.5$ & $8.5 \pm 2.3$ & $8.1 \pm 1.6$ & \\
\hline & Median & 59.3 & 19.0 & $7.6^{x}$ & $8.3^{x}$ & $8.2^{x}$ & \\
\hline & Range & $34.3-123.1$ & $6.8-85.2$ & $4.0-12.4$ & $4.9-14.2$ & $5.6-10$ & \\
\hline \multirow{4}{*}{$\begin{array}{l}\text { Heparin } \\
\text { before } \\
\text { hospitaliza- } \\
\text { tion [IU] }\end{array}$} & Npt (\%) & $8(100)$ & $21(95.4)$ & $0(0)$ & $0(0)$ & $0(0)$ & \\
\hline & Mean \pm SD & $7125 \pm 2315$ & $6405 \pm 2505$ & $0 \pm 0$ & $0 \pm 0$ & $0 \pm 0$ & \\
\hline & Median & 6000 & 5000 & 0 & 0 & 0 & \\
\hline & Range & $5000-10000$ & $5000-10000$ & $0-0$ & $0-0$ & $0-0$ & \\
\hline \multirow{4}{*}{$\begin{array}{l}\text { Heparin } \\
\text { at start } \\
\text { of } \mathrm{PCI}[\mathrm{IU}]\end{array}$} & Npt (\%) & $0(0)$ & $22(100)$ & $10(100)$ & $12(100)$ & $0(0)$ & \\
\hline & Mean \pm SD & $0 \pm 0$ & $7273 \pm 2562$ & $9100 \pm 1114$ & $6167 \pm 1760$ & $0 \pm 0$ & \\
\hline & Median & 0 & 6000 & 10000 & 6000 & 0 & \\
\hline & Range & $0-0$ & $3000-10000$ & $7500-10000$ & $3000-10000$ & $0-0$ & \\
\hline
\end{tabular}

$\mathrm{Npt}$ - number of heparinized patients in particular groups, ${ }^{*} p<0.05,{ }^{x}-$ PAPP-A levels not influenced by previous heparin administration 
Table II. Comparison of PAPP-A normalization between groups with ACS-STE, elective $\mathrm{PCI}$ and angiography patients without $\mathrm{PCl}$

\begin{tabular}{|lccccc|}
\hline & $n / N$ & TR [h] & \multicolumn{3}{c|}{ Statistical comparisons } \\
\hline $\begin{array}{l}\text { ACS-STE } \\
+ \text { UFH and } \\
\begin{array}{l}\text { ACS-STE } \\
+ \text { aUFH }\end{array}\end{array}$ & $24 / 30$ & $12(14-48)$ & $x$ & $x$ & \\
\hline $\begin{array}{l}\text { Elective PCI } \\
+ \text { UFH }\end{array}$ & $9 * / 10$ & $4.3(2-12)$ & $x$ & & $x$ \\
\hline ANG + UFH & $10^{*} / 12$ & $5.4(4-6.3)$ & & $x$ & $x$ \\
\hline Value of $p$ & & & $<0.05$ & $<0.05$ & NS \\
\hline
\end{tabular}

$n-$ number of patients with return of PAPP-A levels $<10 \mathrm{mIU} / \mathrm{l}$ $N$ - number of studied patients, *number of patients with all exami nations within $24 h, x$-comparison of studied patients, TR - time necessary for the PAPP-A return to $<10 \mathrm{mIU} / \mathrm{l}$

cessfully reperfused in 29/30 (96.6\%) of cases. The median duration of intervention was 35 min (range 10-85 min). Stents were used in 29/30 cases (1.27 stents per patient, on average). No drug-eluting stents were used. TIMI 0/1, at the beginning of the procedure, was observed in 22 patients (73.3\%) and final TIMI 2/3 was observed in 28 patients (93.3\%). $\mathrm{Ilb} / \mathrm{Illa}$ inhibitors were used in 5 patients (16.7\%). Two patients had ventricular fibrillation before admission, one during the procedure, in one case we observed the "no-reflow phenomenon" and in two patients distal embolization or occlusion of a side branch. One ACS-STE patient died (3.3\%) on the $45^{\text {th }}$ day from pulmonary embolization.

\section{PAPP-A levels in patients without ACS, before UFH administration}

Median control levels in patients without CAD (ANG-UFH; 40 measurements) from the present study and from the years 2001-2007 (96 patients) corresponded to 6.8 (interquartile range (IR) was 5.6-7.9) and $6.5 \mathrm{mIU} / \mathrm{I}$ respectively [2], without any statistically significant difference $(p=0.39)$. The

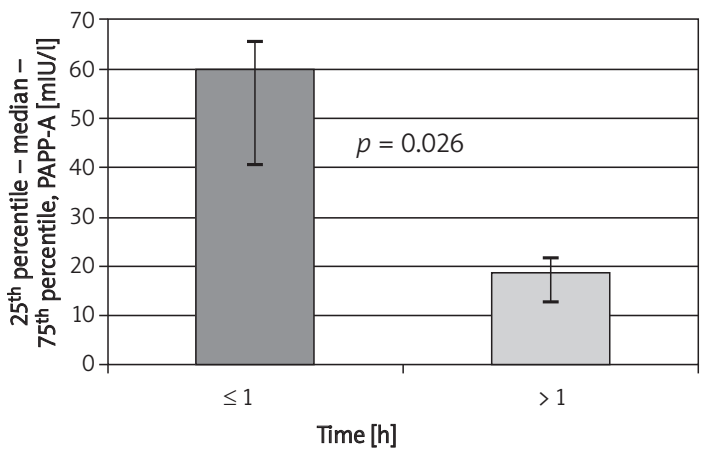

Figure 1. Influence of interval length of the first heparin administration on admission PAPP-A levels in ACS-STE patients

$h$ - interval between UFH administration and admission examination. Only pre-PCI UFH data from 20/29 patients with verified time and UFH dose $95^{\text {th }}$ percentile levels from both studies were in the range of 9.3-9.7 mIU/l. Therefore, the PAPP-A cutoff levels are over $10.0 \mathrm{mIU} / \mathrm{l}$.

The median PAPP-A levels before UFH administration in patients with elective $\mathrm{PCl}$ (elective $\mathrm{PCl}+$ UFH; $7.6 \mathrm{mIU} / \mathrm{l}$; IR 5.8-9.6) or coronary angiography (ANG + UFH; $8.3 \mathrm{mIU} / \mathrm{l} ; \mathrm{IR}$ 6.9-9.6) were all under the $95^{\text {th }}$ percentile cut-off level (Table I).

\section{Impact of UFH/LMWH on PAPP-A levels in ACS-STE patients before and after $\mathrm{PCl}$}

Increased PAPP-A levels in heparinized ACS-STE patients before primary $\mathrm{PCl}$ were found in $28 / 29$ patients (Table I). The median interval from UFH administration to admission/PAPP-A sampling was $90 \mathrm{~min}$; range 15-220 $\mathrm{min}$. In one of the heparinized patients, with a BMI of $27 \mathrm{~kg} / \mathrm{m}^{2}$ and $5000 \mathrm{IU}$ of UFH before admission, the level of PAPP-A remained normal. In one patient without UFH, PAPP-A was $>10 \mathrm{mIU} / \mathrm{I}$ within $120 \mathrm{~min}$ after acute chest pain.

An inverse relationship of the interval length from UFH administration and increased PAPP-A admission levels was revealed (Figure 1). These data indicate that pre-admission clearance of PAPP-A levels was highest within the $1^{\text {st }} \mathrm{h}$ after UFH administration, corresponding to $40 \mathrm{mIU} / \mathrm{l}$ per hour. During the second hour, it fell to $10 \mathrm{mIU} / \mathrm{l}$ per hour.

The admission, pre-PCI PAPP-A levels in the subgroup of ACS-STE patients requiring additional UFH (ACS-STE + aUFH), because of insufficient ACT levels, were lower than in patients with satisfactory anticoagulation for $\mathrm{PCI}-\mathrm{ACS}-\mathrm{STE}+\mathrm{UFH}$ (medians 19.0 (IR 14.7-30.0) vs. 59.3 (34.9-66.5) $\mathrm{mIU} / \mathrm{l}$; $p=0.002$; Figure $2 \mathrm{~A}$ and Table I). This observation was confirmed by a significant relationship between ACT and PAPP-A levels $(r=0.78 ; p=0.0001)$.

The rapid and substantial increase of PAPP-A levels after concomitant $\mathrm{PCl}$ additional heparin in ACSSTE + aUFH patients was followed by a rapid decrease within the first $4 \mathrm{~h}$ (Figure $2 \mathrm{~A}$ ), followed by a slow return to levels $<10 \mathrm{mIU} / \mathrm{l}$ within $12 \mathrm{~h}$. The duration of $\mathrm{PCl}$, indicating the potential clinical severity of the procedure, did not influence PAPP-A levels. Pregnancy-associated plasma protein-A levels after $\mathrm{PCl}$ lasting $\leq 30$ min compared to $31-60$ min PCI were 91.7 (IR was 64.6-144.9) vs. 77.9 (IR 45.8-163.4) $\mathrm{mIU} / \mathrm{l} ; p=0.63$.

The direct impact of UFH administration on increasing PAPP-A levels was related to its dosage, with a rapid increase within the $1^{\text {st }} \mathrm{h}$ (Figure $2 \mathrm{~B}$ ) and return to normal levels within $12 \mathrm{~h}$. Patients with a lower level of ACT corresponding to lower admission level of PAPP-A received a higher dose of heparin (10 000 IU) concomitantly with $\mathrm{PCl}$ that induced the highest level of PAPP-A after the end of $\mathrm{PCl}$ (Figure $2 \mathrm{~B}$ ). A significant increase of PAPP-A levels was also observed 


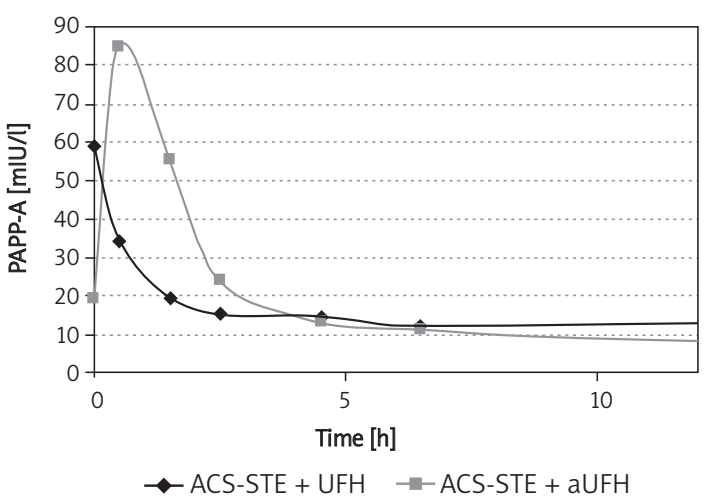

Figure $2 \mathrm{~A}$. The PAPP-A time course in ACS-STE with and without $\mathrm{PCl}$ concomitant additional heparin administration

$O h-P A P P-A$ levels within interval between admission and start of $P C l$

after LMWH administration (11.7 (IR 10.1-17.1) vs. 9.1 (7.6-11.1) $\mathrm{mIU} / \mathrm{l} ; p=0.005)$, applied within $24 \mathrm{~h}$ after $\mathrm{PCl}$, to prevent imminent thrombotic complications.

\section{Impact of UFH on PAPP-A levels in patients without ACS}

The identical rapid, large increase of PAPP-A levels, after UFH administration before elective PCI or coronary angiography, provides evidence that $\mathrm{UFH}$ is mainly responsible for the rapid release of PAPP-A and is not related to the CAD, PCl or angiography. The PAPP-A peak level appeared 20 min after the start of the procedures; levels in diagnostic angiography without UFH remained unchanged, under the cut-off level.

The dynamics of the initial PAPP-A level changes in patients with elective $\mathrm{PCl}$ and angiography with UFH were similar to those in heparinized ACS-STE patients. Our pilot study data indicate that the normalization of PAPP-A levels is quicker, i.e. within 4 to $5 \mathrm{~h}$, than in ACS-STE patients (Table II). The median time needed for normalization of PAPP-A levels in ACS-STE patients was $12.0 \mathrm{~h}$, whereas in heparinized patients with elective $\mathrm{PCl}$ and angiography it was $4.33 \mathrm{~h}$ and $5.45 \mathrm{~h}$, respectively ( $p<0.05$; Table II). The ACS-STE patients with additional LMWH administration after $\mathrm{PCl}$ were eliminated from this comparison (Figure 3).

\section{ACS-STE patients without laboratory normalization of PAPP-A within $24 \mathrm{~h}$ after $\mathrm{PCl}$}

In 7/30 STEMI patients, PAPP-A levels > $10 \mathrm{mIU} / \mathrm{l}$ persisted even after $24 \mathrm{~h}$. In 2/7 patients, a large groin haematoma was observed. In 1 patient severe three-vessel disease was found and in one $\mathrm{PCl}$ failed to open the infarcted artery. In 3/7 patients, hospitalization ran a normal course.

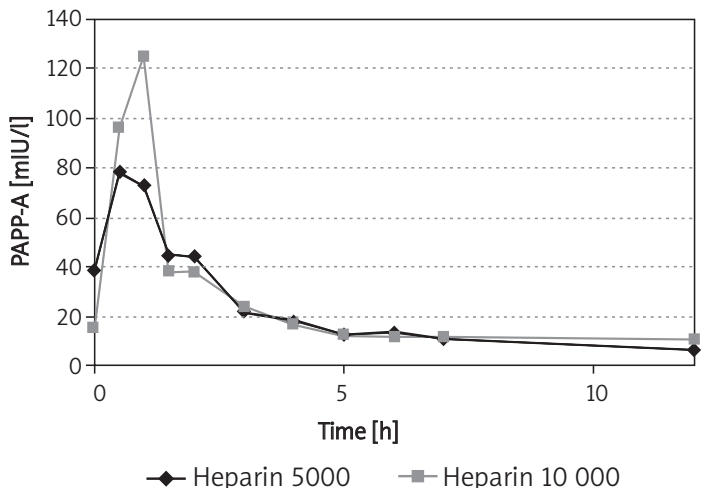

Figure $2 \mathrm{~B}$. Influence of heparin dose in ACS-STE

\section{Discussion}

Exact timing of PAPP-A examination allowed the ascertainment of its diagnostic validity by evaluation of the influence of $\mathrm{PCl}$-angiography procedures, early clinical complications and heparin application.

To our best knowledge, this is the first systematic PAPP-A ACS-STE study without any patient selection bias that confirms previous suggestive evidence concerning UFH/LMWH influence on increased PAPP-A levels in serum of ACS-STE patients $[6,8,9]$.

Detected levels of PAPP-A can be influenced by assay sensitivity and antibody specificity [11]. The examination of frozen sera using the Kryptor ${ }^{T M}$ system assured rapid and reliable examination of total PAPP-A levels, with the same cut-off level of $<10 \mathrm{mIU} / \mathrm{l}$ as in other studies $[3,8]$.

Admission PAPP-A levels were increased in all ACS-STE patients who had been heparinized before admission, except for a patient (BMI $27 \mathrm{~kg} / \mathrm{m}^{2}$ ) with an insufficient dose of heparin. The increased

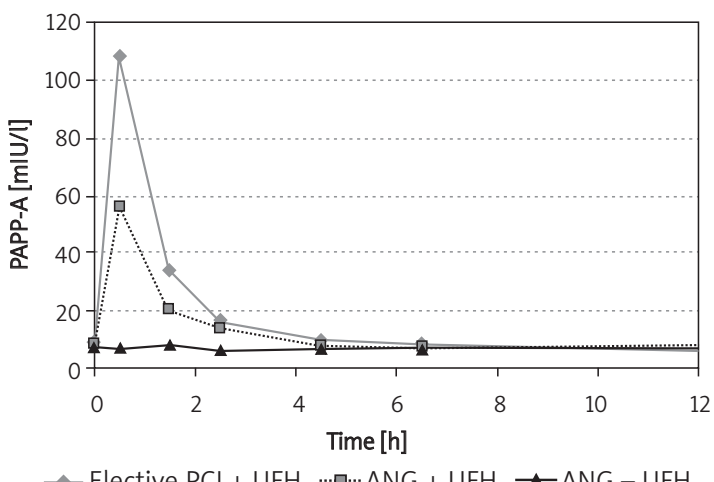

Figure 3. The PAPP-A time course in elective PCI with concomitant UFH and in coronary angiography with/without UFH

Levels of PAPP-A before procedure were under cut-off level $<10 \mathrm{mIU} / \mathrm{l}$ in both studied groups. O h - PAPP-A levels before the start of the procedure 
PAPP-A level in a patient without heparin, $2 \mathrm{~h}$ after the onset of acute chest pain, suggests that increased PAPP-A might be a valuable biomarker within the $1^{\text {st }} \mathrm{h}$ of ACS before the first UFH/LMWH administration.

Heparin administration was associated with a rapid and substantial PAPP-A increase, not only in ACS-STE patients (Figures $2 \mathrm{~A}-\mathrm{B}$ ), but also in all patients without ACS and even in patients without angiographic signs of significant atherosclerosis (Figure 3). Angiography, without UFH, did not cause PAPP-A increase (Figure 3). Therefore, increases in PAPP-A are directly linked to UFH or LMWH administration $[8,9]$.

The effect of heparin on PAPP-A levels increase was directly related to the therapeutic dose (Figure 2 B), significantly correlated with ACT levels and inversely correlated with the interval between application and time of serum sampling (Figure 1). This corresponds to our observation that in ACS-STE patients, without necessary PCI concomitant heparin administration because of high ACT, the PAPP-A levels were significantly increased without the typical peak directly after PCI UFH application (Figure $2 \mathrm{~A}$ ), followed by a continual PAPP-A decrease.

The PAPP-A level increase appeared not to be significantly dependent on the performance of $\mathrm{PCl}$ and its length, or on diagnostic arteriography (Figure 3), suggesting that the rapid PAPP-A increase after $\mathrm{PCl}$ is mainly due to the additional heparin administration [8].

The rapid increase of PAPP-A after PCI concomitant UFH therapy was followed by a rapid decrease within $1-2 \mathrm{~h}$, with return to normal levels $<10 \mathrm{mIU} / \mathrm{l}$ in $80 \%$ of ACS-STE patients (24/30) within $10-12 \mathrm{~h}$, in agreement with previous data [8], compared to a more rapid normalization in heparinized elective $\mathrm{PCl}$ and angiography patients (Table II, Figures 2 A-B and Figure 3). The slower return to normal PAPP-A levels in ACS-STE patients and persistence of increased PAPP-A in some of them might also be related to atherosclerotic lesions/plaque instability. Moreover, PAPP-A levels > $10 \mathrm{mIU} / \mathrm{l}$ persisting in ACS-STE patients after $24 \mathrm{~h}$ might also be associated with serious clinical complications, such as large groin haematomas, unsuccessful opening of an infarct artery or severe three-vessel disease. The impact of different early complications in ACS-STE patients on PAPP-A levels should be verified by further studies.

Our results indicate that the individual prognostic validity of PAPP-A levels in ACS can be verified not earlier than $12 \mathrm{~h}$ after UFH application (Table II), if the ACT control levels are in the normal range and if other clinical complications, including tumours, are excluded [12]. It is necessary to consider also individual variation in pharmacogenetic inactivation of UFH/LMWH.
Increased release of PAPP-A from unstable plaque or an affected coronary artery wall after plaque abruption is supported by slower clearance of PAPP-A in ACS-STE patients and the (otherwise unexplained) persistence of $>10 \mathrm{mIU} / \mathrm{l}$ levels after $24 / 48 \mathrm{~h}$ in some of our patients. Our findings are in agreement with previous observations that increased PAPP-A levels in pre-transplant plasma are predictive of post-transplant cardiovascular events [13], including an increased risk of death in AMI patients with initially elevated PAPP-A levels [14].

The mechanism of rapid PAPP-A increase in heparinized ACS-STE, elective $\mathrm{PCI}$, and angiography patients without CAD might be explained by the affinity of heparin to PAPP-A [15]. Moreover, heparin effectively competes for PAPP-A cell surface binding sites [16], which might explain the rapid PAPP-A increase, since PAPP-A is expressed ubiquitously in human coronary artery endothelium and vascular smooth muscle [17]. This explanation is supported by our finding of a UFH dose-related PAPP-A increase in patients without ACS, as well as in heparinized dialysis and angiography patients [9].

Increased PAPP-A levels might also be due to its strong expression in atherothrombotic plaques in vivo [18] in ACS-STE patients. This is in agreement with the observed slower clearance of UFH in our patients and the persistence of increased levels, in some patients, after $48 \mathrm{~h}$. Increased levels of the free PAPP-A fraction, in ACS without ST segment elevation and UFH administration before admission, provide additive prognostic information of 1-year outcome in forecasting death and non-fatal myocardial infarction $[19,20]$.

UFH-induced rapid release of PAPP-A from coronary vessel walls may also contribute to the stabilization of ruptured plaques, since PAPP-A proteolytic activity is bound, by adhesion, to cell surfaces and makes IGF-1 available through cleavage of IGFBP-4 [8]. The beneficial role of UFH due to the massive release of PAPP-A, not only from coronary arteries, might enhance the influx of growth factors, which target damaged myocardial cells in response to the accompanying increase of IGF-1 [21] corresponding to PAPP-A accumulation in healing tissues [22].

Clearance of PAPP-A includes not only elimination by the kidneys, but also its re-association with cell surfaces, presumably in damaged regions. This possibility is suggested by our observation that the rapid, UFH dose-related increase of PAPP-A does not influence the time of its rapid decrease (Figure $2 \mathrm{~B}$ ).

Heparin is recognized as an anticoagulation strategy in ACS-STE patients treated with $\mathrm{PCI}$ [23]. Nevertheless, our results provide evidence that in heparin treated ACS-STE patients, PAPP-A does not have diagnostic validity as an early biomarker. Diagnostic validity of PAPP-A in ACS requires PAPP-A 
ascertainment before the first UFH/LMWH application within the first few hours after clinical onset. Prognostic implementation has to take into account the time of UFH/LMWH administration, its clearance and concomitant serious clinical complications.

Our results have to be confirmed by further studies in all types of ACS. Our PAPP-A examination is based on the ascertainment of total PAPP-A levels without evaluation of roles of uncomplexed PAPP$A$ and proMBP, which is associated with PAPP-A and regulates its physiological activity [4].

\section{Acknowledgments}

Supported by MZOFNM2005. Critical review of Prof. M. Macek Jr, MD, DSc is appreciated. Petr Hájek and Milan Macek Sr. contributed equally to this work.

\section{References}

1. Iversen KK, Teisner AS, Teisner B, et al. Pregnancy associated plasma protein $\mathrm{A}$, a novel, quick, and sensitive marker in ST-elevation myocardial infarction. Am J Cardiol 2008; 101: 1389-94.

2. Hájek P, Macek M, Hladíková M, et al. Pregnancy-associated plasma protein $\mathrm{A}$ and proform eosinophilic major basic protein in the detection of different types of coronary artery disease. Physiol Res 2008; 57: 23-32.

3. Bayes-Genis A, Conover CA, Overgaard MT, et al. Pregnancy-associated plasma protein $A$ as a marker of acute coronary syndromes. N Engl J Med 2001; 345: 1022-9.

4. Cosin-Sales J, Christiansen M, Kaminski P, et al. Pregnancy-associated plasma protein $\mathrm{A}$ and its endogenous inhibitor, the proform of eosinophil major basic protein (proMBP), are related to complex stenosis morphology in patients with stable angina pectoris. Circulation 2004; 109: 1724-8.

5. Lund J, Qin QP, Ilva T, et al. Circulating pregnancy-associated plasma protein a predicts outcome in patiens with acute coronary syndrome but no troponin I elevation. Circulation 2003; 108: 1924-6.

6. Lund J, Qin QP, Ilva T, et al. Pregnancy-associated plasma protein A: a biomarker in acute ST-elevation myocardial infarction (STEMI). Ann Med 2006; 38: 221-8.

7. Brügger-Andersen T, Hetland $\emptyset$, Pönitz V, Grundt H, Nilsen DW. The effect of primary percutaneous coronary intervention as compared to tenecteplase on myeloperoxidase, pregnancy-associated plasma protein A, soluble fibrin and D-dimer in acute myocardial infarction. Thromb Res 2007; 119: 415-21.

8. Terkelsen CJ, Oxvig C, Nørgaard BL, et al. Temporal course of pregnancy-associated plasma protein-A in angioplasty-treated ST-elevation myocardial infarction patients and potential significance of concomitant heparin administration. Am J Cardiol 2009; 103: 29-35.

9. Tertti R, Wittfooth S, Porela P, Airaksinen KE, Metsärinne K, Pettersson K. Intravenous administration of low molecular weight and unfractionated heparin elicits a rapid increase in serum pregnancy-associated plasma protein $\mathrm{A}$. Clin Chem 2009; 55: 1214-7.

10. Lohse H, Ludwig R, Röhr M. Statistische Verfahren für Psychologen, Pädagogen und Soziologen. Berlin VWVV, 1982; 132.
11. Rossen M, Iversen K, Teisner A, Teisner B, Kliem A, Grudzinskas G. Optimisation of sandwich ELISA based on monoclonal antibodies for the specific measurement of pregnancy-associated plasma protein (PAPP-A) in acute coronary syndrome. Clin Biochem 2007; 40: 478-84.

12. Bulut I, Coskun A, Ciftci A, et al. Relationship between pregnancy-associated plasma protein-A and lung cancer. Am J Med Sci 2009; 337: 241-4.

13. Lauzurica R, Pastor C, Bayés B, Hernández JM, Romero R. Pretransplant pregnancy associated plasma protein-a as a predictor of chronic allograft nephropathy and posttransplant cardiovascular events. Transplantation 2005; 80: 1441-6.

14. Iversen KK, Dalsgaard M, Teisner AS, et al. Usefulness of pregnancy-associated plasma protein A inpatients with acute coronary syndrome. Am J Cardiol 2009; 104: 1465-71.

15. Davey MW, Teisner B, Sinosich M, Grudzinskas JG. Interaction between heparin and human pregnancy-associated plasma protein A (PAPP-A): a simple purification procedure. Anal Biochem 1983; 131: 18-24.

16. Weyer K, Overgaard MT, Laursen LS, et al. Cell surface adhesion of pregnancy-associated plasma protein- $A$ is mediated by four clusters of basic residues located in its third and fourth CCP module. Eur J Biochem 2004; 271: 1525-35.

17. Glerup S, Kløverpris S, Oxvig C. The proform of the eosinophil major basic protein binds the cell surface through a site distinct from its C-type lecitin ligand-binding region. J Biol Chem 2006; 281: 31509-16.

18. Conover CA, Harrington SC, Bale LK. Differential regulation of pregnancy associated plasma protein-A in human coronary artery endothelial cells and smooth muscle cells. Growth Horm IGF Res 2008; 18: 213-20.

19. Lund J, Wittfooth S, Qin QP, et al. Free vs total pregnancy-associated plasma protein A (PAPP-A) as a predictor of 1-year outcome in patients presenting with non-STelevation acute coronary syndrome. Clin Chem 2010; 56: 7.

20. Iversen KK, Dalsgaard M, Teisner AS, et al. Pregnancyassociated plasma protein-A, a marker for outcome in patients suspected for acute coronary syndrome. Clin Biochem 2010; 43: 851-7

21. Liu ZY, Zhang JY, Sun TW, et al. Levels of pregnancy-associated plasma protein A in patients with coronary artery disease. Clin Invest Med 2008; 31: E 85-9.

22. Chen BK, Leiferman KM, Pittelkow MR, Overgaard MT, Oxvig C, Conover CA. Localization and regulation of pregnancy-associated plasma protein a expression in healing human skin. J Clin Endocrinol Metab 2003; 88: 4465-71.

23. Grabowski M, Leszczyk M, Cacko A, Filipiak KJ, Opolski G. Acute management of ACS. Anticoagulation therapy in acute coronary syndromes according to current guidelines. Arch Med Sci 2010; 6 (Suppl 1A): S29-34. 